\title{
Author Correction: The LipoGlo reporter system for sensitive and specific monitoring of atherogenic lipoproteins
}

\author{
James H. Thierer (1), Stephen C. Ekker (1) \& Steven A. Farber (D)
}

Correction to: Nature Communications https://doi.org/10.1038/s41467-019-11259-w, published online 31 July 2019.

The original version of this Article contained errors in Fig. 3 and in the Source data file, for which the authors apologise. In Fig. $3 c$, the gels representing $m t p^{-l-}$ and $a p o C 2^{-l-}$ were switched, and the labels on the left of this panel were incorrectly positioned; moreover, in Fig. $3 \mathrm{f}$ and g, the chart titles were omitted. In the Source data file for Fig. 3f, the values for the 5-dpf and 6-dpf wild-type samples were identical. These errors originated when the data from the original files were compiled into the source data and did not affect any figures or quantifications.

The errors have been corrected in both the PDF and HTML versions of the Article, and the Source Data file has been amended to include the correct values for the samples corresponding to Fig. $3 \mathrm{f}$.

Published online: 21 July 2020

\footnotetext{
(c) (i) Open Access This article is licensed under a Creative Commons Attribution 4.0 International License, which permits use, sharing, adaptation, distribution and reproduction in any medium or format, as long as you give appropriate credit to the original author(s) and the source, provide a link to the Creative Commons license, and indicate if changes were made. The images or other third party material in this article are included in the article's Creative Commons license, unless indicated otherwise in a credit line to the material. If material is not included in the article's Creative Commons license and your intended use is not permitted by statutory regulation or exceeds the permitted use, you will need to obtain permission directly from the copyright holder. To view a copy of this license, visit http://creativecommons.org/licenses/by/4.0/.
}

(c) The Author(s) 2020 